4. Згуровский М. Г. В водовороте глобализации: вызовы и возможности / М. Г. Згуровский // Зеркало недели. Украина. - № 45. - [Електронний ресурс]. Режим доступу до статті: http:/gazeta.zn.ua/ SCIENCE /v_vodovorote_globalizatsii_vyzovy_i_vozmozhnosti.html. 5. Зинченко В. П. Психологическая педагогика. Материалы к курсу лекций. Часть І. Живое знание / В. П. Зинченко. - Самара : Издательство СГПУ, 1998. - 216 с. б. Канаев Н. М. Глобализация и высшее образование. Взгляд из ЮНЕСКО / Н. М. Канаев // Философия образования. - 2005. - № 1 (12). - С. 26-31. 7. Кисельов М. М. Національне буття серед екологічних реалій / М. М. Кисельов, Ф. М. Канак. - К. : Тандем, 2000. - 273 с. 8. Кисельов М. М. Концептуальні виміри екологічної свідомості / М. М. Кисельов, В. Л. Деркач, А. В. Толстоухов. - К. : Вид. Парапан, 2003. - 312 с. 9. Кушнарьова Н. Б. Основні тенденції розвитку масової культури в сучасній Україні в контексті глобалізації. Українські культурні дослідження / Н. Б. Кушнарьова. - [Електронний ресурс]. - Режим доступу до статті: http://www.culturalstudies.in.ua/ zv_2005_s6.php. 10. Основи викладання мистецьких дисциплін: [навч. посіб.]. за заг. ред. О. П. Рудницької. - К. : АТЗС «Експрес-об’ява», 1998. - 114 с. 11. Шинкаренко О. В. Природа і культура. Історія світової культури / О. В. Шинкаренко. - К. : Либідь, 2003. - 253 с.

УДК $378.14+372$.

Крістіна Тамбовська

\title{
ІНТЕЛЕКТУАЛЬНА КУЛЬТУРА Й ІНТЕЛЕКТУАЛЬНИЙ РОЗВИТОК ФАХІВЦЯ ЯК СТРАТЕГІЧНА МЕТА ЯКІСНОЇ ПЕДАГОГІЧНОЇ ОСВІТИ
}

Тамбовська К. В. Інтелектуальна культура й інтелектуальний розвиток фахівця як стратегічна мета якісної педагогічної освіти.

У статті розглянуто проблему визначення інтелектуальної культури, яка розуміється нами як складне особистісне утворення і визначається з урахуванням етимології понять «інтелект» і «культура», ураховує специфіку професійно значущих рис особистості майбутнього вчителя початкової школи, передбачає реалізацію визначених функцій у системі професійної діяльності та сфері особистого життя.

Ключові слова: інтелект, культура, інтелектуальна культура, інтелектуальний розвиток фахівця, вчитель початкової школи.

Тамбовская К. В. Интеллектуальная культура и интеллектуальное развитие специалиста как стратегическая цель качественного педагогического образования.

В статье рассмотрино проблема определения интеллектуальной культуры, которая понимается нами как сложное личностное образование и определяется исходя из этимологии понятий «интеллект» и «культура», учитывает специфику профессионально значимых черт личности будущего учителя начальной школы, предусматривает реализацию определенных функций в системе профессиональной деятельности и сфере личной жизни.

Ключевые слова: интеллект, культура, интеллектуальная культура, интеллектуальное развитие специалиста, учитель начальной школы.

Tambovskaya K. V. Intellectual culture and intellectual development of specialist as a strategic aim of quality pedagogical education. 
Studying of a problem of definition of intellectual culture, which is considered by us as difficult personal education and is defined proceeding from etymology of the concepts «intelligence» and «culture», considers specifics of professionally meaning lines of the identity of future elementary school teacher, provides realization of certain functions in system of professional activity and the sphere of private life.

Key words: intelligence, culture, intellectual culture, intellectual development of specialist, teacher of initial school.

Як відомо, інтелектуальна культура особистості формується у спеціально організованому середовищі, потребує для свого розвитку особливих чинників, якими для майбутнього вчителя $\epsilon$ засоби організації навчально-виховного процесу педагогічного ВНЗ. Інтелектуальна культура, як свідчать вітчизняні та закордонні дослідження, формується протягом усього життя людини, однак найбільш інтенсивно в період юності, під час спеціально організованого впливу, під час засвоєння, наслідування й удосконалення зразків інтелектуальної культури цивілізації, професійного становлення й самоактуалізації в обраній галузі суспільного життя.

Ретроспективний аналіз ідей відомих педагогів і просвітителів минулого й сьогодення надав змогу виокремити важливість культурологічного та розвивального складників у змісті освіти та професійної підготовки майбутнього вчителя. 3'ясовано, що сучасний етап розвитку педагогічної освіти характеризується заміною парадигми раціонального знання парадигмою культуровідповідної та культуротворчої освіти, коли в центрі уваги постає особистість того, хто навчається, та його педагога, їх культури діяльності, поведінки, мислення, співпраці; а знання й уміння, якими вони володіють, із самоцілі перетворюються на засоби самореалізації особистості, іii всебічного розвитку. Головним принципом культурологічного підходу в системі педагогічної освіти $є$ формування професійно-педагогічної культури, яка розглядається як похідна від загальної культури особистості майбутнього вчителя та містить у собі, 3-поміж інших, культуру інтелектуальну. У контексті культурологічного підходу формування інтелектуальної культури сприймається як процес, здійснюваний на засадах раціогуманізму в культуровідповідньому освітньому середовищі, й наповнений індивідуально-ціннісними змістами.

Mema cmammi - окреслити розуміння поняття «інтелектуальна культура», яка розглядається нами як складне особистісне утворення і визначається, грунтуючись на етимології понять «інтелект» і «культура», ураховує специфіку професійно значущих рис особистості майбутнього вчителя початкової школи, передбачає реалізацію визначених функцій у системі професійної діяльності й галузі особистого життя. Інтелектуальною культурою $є$ складне динамічне утворення, характеристика такого якісного рівня діяльності майбутнього вчителя в галузі пізнання й педагогічної практики, що забезпечує конкретизацію i трансляцію ним загальнолюдських цінностей і як наслідок - створення нового пізнавального продукту, ефективну взаємодію з учнями, професійний та особистісний саморозвиток.

Останні публікації з теми дослідження. В. Андреєв, Г. Балл, С. Біблер, С. Гессен, О. Новиков, М. Розов, В. Луговий, В. Сластьонін та інші розглядають «культуру» як родове поняття стосовно поняття «освіта», де освіта визначається як індивідуальна культура різних видів діяльності й спілкування людини, що опановує культурою на основі цілеспрямованої й цілісної системи навчання й виховання. Основні функції культури особистості визначено у філософській літературі (А. Арнольдов, П. Гуревич, В. Давидович, Т. Іванова, М. Каган, Л. Коган, Н. Крилова, Е. Маркарян, В. Межуєв, 
В. Шубін та ін.). Установлено, що найбільш загальною й універсальною функцією культури є адаптивна - пристосування людини до природного й соціального оточення шляхом засвоєння культурних зразків. Базова адаптивна функція культури конкретизується в низці інших, часткових функцій. Найбільш значущими серед них є: пізнавальна (гносеологічна), ціннісна (аксіологічна), інформаційно-комунікативна; нормативна (регулятивна), знакова (семіотична) функції.

На сучасному етапі численними дослідженнями доведено, що навчання різним професіям виявляється практично рівною мірою залежним від рівня інтелекту майбутнього фахівця. С. Єлканов наголошує на таких інтелектуальних ознаках професійної культури, як: гармонійний розумовий, моральний та естетичний розвиток, широкий науковий i художньо-естетичний світогляду, здатність легко i природно входити у творчий стан, уміння аналізувати свої емоційні, вольові процеси [2, с. 19-20].

На думку В. Семиченко, з-поміж компонентів професійної культури можна виокремити такі: науковий світогляд, оволодіння складними прийомами роботи 3 будь-якою інформацією, розвиток i професіоналізація мислення, формування індивідуального стилю діяльності, засвоєння творчого підходу до розв'язання пізнавальних і практичних завдань, формування стійкої професійної позиції тощо. [5].

Ми розуміємо відмінність між педагогічною i професійно-педагогічною культурою, оскільки перша може реалізовуватися не педагогічними працівниками i тому $\epsilon$ більш загальним поняттям і невід'ємним складником останнім. Але звертаємося до пропонованих трактувань для того, щоб виявити у структурі професійно-педагогічної культури місце для інтелектуальної культури.

За Т. Івановою, педагогічна культура, з одного боку, - це особлива підсистема, особливий вид культури, а з іншого, - вона, як елемент, присутня в кожному 3 видів культури, пов'язуючи його із системою соціального спадкування, утворюючи своєрідний «каркас» високої духовної культури педагога [3].

Науковець І. Пальшкова розглядає професійно-педагогічну культуру як особливий різновид педагогічної культури суспільства, в якому сконцентровано досвід спеціальної суспільної практики організації навчання і виховання підростаючого покоління в закладах освіти задля задоволення конкретних потреб певного суспільства, способів реалізації освітньо-педагогічної діяльності, соціальних вимог, що її нормують, та способів оволодіння даною діяльністю [4].

Професійно-педагогічна культура визначається В. Гриньовою як діалектична інтегрована єдність педагогічних цінностей: цінностей-цілей і цінностей-мотивів; цінностей-знань; технологічних цінностей; цінностей-властивостей; цінностейставлень. Вони є свого роду вісями координат, на основі яких окреслюється модель професійно-педагогічної культури, які спрямовують і коригують у соціальному, духовному, професійному, особистісному просторі діяльності педагога, його перфекціонізм [1, с. 356]. Поряд із професійно-спрямованими параметрами й індивідуально-психологічними якостями В.Гриньова акцентує у структурі професійно-педагогічної культури на таких інтелектуальних: гнучкості, варіативності, самостійності, критичності, продуктивності, ерудиції, достатній пам'яті, дотепності вчителя, володінні ним усною та писемною мовою, що мають узагальнений характер та можуть бути застосованими вчителем до різного змісту та в різних галузях діяльності [1]. Професійно-педагогічна культура $€$ багатовимірною цілісністю, не останнє місце 3-поміж яких посідають цінності й компоненти інтелектуальної діяльності. В.Гриньова виокремлює у професійно-педагогічній культурі певні 
«горизонтальні шари» конкретної особистості, які взаємопов'язані між собою: інформаційний, технологічний та аксіологічний. Інформаційний шар культури формується у процесі засвоєння особистістю знань, які $є$ базовими для людства, конкретного суспільства, групи людей, і пов'язані з цим процесом. Зважаючи на вищезазначене, розглядаємо інтелектуальну культуру майбутнього вчителя як невід'ємний складник його професійно-педагогічної культури та вважаємо, що завдання іiі формування у процесі професійної підготовки виходять із сучасної культурологічної освітньої парадигми, оскільки духовна сутність інтелектуальної культури - це гуманістична, людинотворча діяльність, яка полягає в конкретизації загальнолюдських цінностей у галузі пізнання, суспільної практики, професійної діяльності. У контексті культурологічного підходу формування інтелектуальної культури сприймається як процес, здійснюваний у культуровідповідньому освітньому середовищі й наповнений індивідуально-ціннісними змістами, грунтується на низці принципів, 3-поміж яких провідним є принцип раціогуманізму, що у світоглядному плані визнає інтелектуальну культуру одним із найважливіших надбань людства, а в плані методології людинознавства слугує розширенню знань про людину i їх гуманістично орієнтованому практичному застосуванню. 3 огляду на це виникає питання щодо пошуку сутності та змісту інтелектуальної культури майбутнього вчителя початкової школи (табл. 1).

Таблицяя 1

\section{Структурні аспекти інтелектуальної культури майбутнього вчителя початкової школи}

\begin{tabular}{|c|c|}
\hline $\begin{array}{c}\text { Структурний елемент - базова } \\
\text { характеристика інтелектуальної } \\
\text { культури }\end{array}$ & $\begin{array}{c}\text { Підструктура елемента - } \\
\text { специфічна характеристика }\end{array}$ \\
\hline 1 & 2 \\
\hline $\begin{array}{l}\text { Культура мислення - дисципліна } \\
\text { розуму, що базується на сформованій у } \\
\text { навчальній діяльності цілісній і гнучкій } \\
\text { системі знань, умінь і навичок, } \\
\text { придатних для пізнання об'єктивного } \\
\text { світу, самого себе й для організації } \\
\text { конструктивної взаємодії } 3 \text { іншими } \\
\text { людьми. }\end{array}$ & $\begin{array}{l}\text { Культура науково-педагогічного } \\
\text { мислення - здатність до діалектичного } \\
\text { погляду на явища педагогічної дійсності, } \\
\text { що дозволяє вчителеві сприймати їі як } \\
\text { процес, де через боротьбу нового зі } \\
\text { старим відбувається безперервний } \\
\text { розвиток; впливати на цей процес, вчасно } \\
\text { розв'язуючи всі питання й завдання, що } \\
\text { виникають у його діяльності питання й } \\
\text { завдання. }\end{array}$ \\
\hline $\begin{array}{l}\text { Культура мовлення - це володіння } \\
\text { нормами усної й письмової літературної } \\
\text { мови (правилами вимови, наголосу, } \\
\text { граматики, слововживання й тощо), а } \\
\text { також уміння використовувати виразні } \\
\text { мовні засоби в різних умовах } \\
\text { спілкування відповідно до мети і змісту } \\
\text { мовлення (Л. Скворцов ) }\end{array}$ & \begin{tabular}{llr}
\multicolumn{2}{c}{ Культура професійного } & мовлення - \\
здатність до чіткого & передавання \\
інформації, генерування педагогічного \\
впливу та та налагоджування \\
конструктивної взаємодії між суб'єктам \\
педагогічного процесу
\end{tabular} \\
\hline
\end{tabular}




\begin{tabular}{|c|c|}
\hline $\begin{array}{c}\text { Структурний елемент - базова } \\
\text { характеристика інтелектуальної } \\
\text { культури } \\
\end{array}$ & $\begin{array}{c}\text { Підструктура елемента - } \\
\text { специфічна характеристика }\end{array}$ \\
\hline $\begin{array}{l}\text { Культура розумової праці- } \\
\text { інтегрована якість особистості, яка } \\
\text { володіє спеціальними знаннями, } \\
\text { уміннями, навичками організації своєї } \\
\text { праці відповідно до наявних } \\
\text { індивідуальних ресурсних можливостей, } \\
\text { забезпечуючи ефективність пізнавальної } \\
\text { діяльності майбутнього педагога. }\end{array}$ & 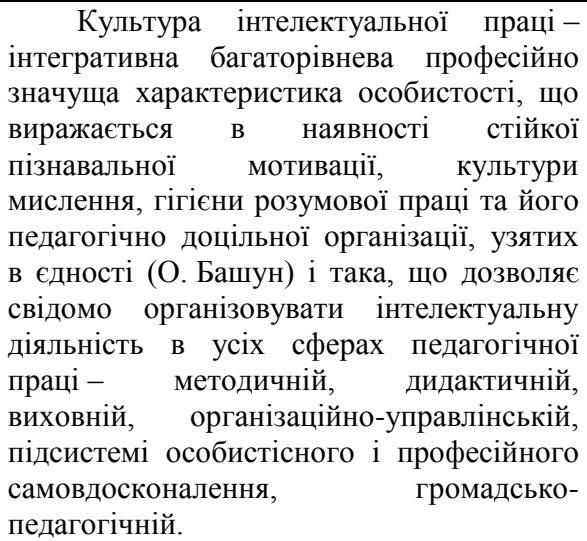 \\
\hline $\begin{array}{l}\text { Культура навчальної діяльності- } \\
\text { інтегративна } \\
\text { осорактеристика } \\
\text { здійснювати що відображає ії здатність } \\
\text { контексті сучасної культури та визначає } \\
\text { ціннісно-змістові орієнтири певного } \\
\text { процесу, а також припускає високий } \\
\text { рівень розвитку і взаємодії структурних } \\
\text { компонентів навчальної діяльності } \\
\text { (В. Крайник) }\end{array}$ & 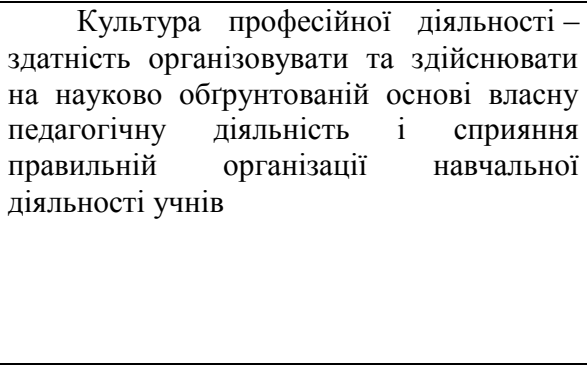 \\
\hline
\end{tabular}

Інтелектуальна культура розглядається нами, виходячи 3 етимології понять «інтелект» i «культура», як складне динамічне утворення, характеристика такого якісного рівня діяльності майбутнього вчителя в галузі пізнання й педагогічної практики, що забезпечує конкретизацію і трансляцію загальнолюдських цінностей, i як наслідок - створення нового пізнавального продукту, ефективну взаємодію 3 учнями, професійний та особистісний саморозвиток.

Отже, зроблений нами огляд надав змогу з'ясувати, що поняття «інтелектуальна культура» не є простим механічним поєднанням понять «культура» й «інтелект». У першому наближенні інтелектуально культурою слід уважати синтез, органічний сплав, що детермінує нове суспільне явище, особистісне утворення, яке характеризує високий рівень інтелектуальної діяльності людини, як носія загальної культури та їі транслятора в галузі пізнання й суспільної практики, зумовлює його здатність до створення нового пізнавального продукту.

Отже, під інтелектуальною культурою майбутнього вчителя початкової школи будемо розуміти складне динамічне утворення, характеристику такого якісного рівня діяльності майбутнього вчителя в галузі пізнання й педагогічної практики, що забезпечує конкретизацію і трансляцію загальнолюдських цінностей, і як наслідокстворення нового пізнавального продукту, ефективну взаємодію 3 учнями, професійний та особистісний саморозвиток. Подальшу свою роботу ми вбачаємо в 
розробленні діагностувальних методик визначення рівня інтелектуальної культури.

\section{Література}

1. Гриньова В. М. Формування педагогічної культури майбутнього вчителя (теоретичний та методичний аспект) / В. М. Гриньова. - Х. : Основа, 1999. - 300 с. 2. Елканов С. Б. Основы профессионального самовоспитания будущего учителя / Самсадин Бутохович Елканов. - М. : Просвещение, 1989. - 175 с. З. Иванова Т. В. Культурологическая подготовка будущего учителя : [монография]/ Татьяна Викторовна Иванова. - К. : ЦВП, 2005. - 282 с. 4. Пальшкова І. О. Практикоорієнтований підхід у формуванні професійно-педагогічної культури вчителів початкової школи : [монографія] / Ірина Олександрівна Пальшкова. - Одеса : Букаєв Вадим Вікторович, 2009. - 339 с. 5. Семиченко В. А. Пути повышения эффективности изучения психологии / Валентина Анатолиивна Семиченко. - К. : Магістр-в, 1997. - 124 с.

\section{ІМЕРСІЙНА ОСВІТА В КАНАДІ ЯК ЕФЕКТИВНИЙ ЗАСІБ ВИВЧЕННЯ ДРУГОЇ МОВИ}

Устименко В. В. Імерсійна освіта в Канаді як ефективний засіб вивчення другої мови.

У статті розглядається досвід використання французьких імерсійних програм в освіті Канади, розкриваються характерні особливості такого виду навчання, зважаючи на потреби сучасного канадського суспільства. Особлива увага звертається на ефективність імерсійної освіти під час засвоєння другої мови.

Ключові слова: Канада, імерсійна освіта, імерсійні програми, мультилінгвізм.

Устименко В. В. Иммерсионное образование в Канаде как эффективный способ изучения второго языка.

В статье рассматривается опыт использования французских иммерсионных программ в образовании Канады, раскрываются характерные особенности такого вида обучения, учитывая потребности современного канадского общества. Особое внимание уделяется эффективности иммерсионного образования при освоении второго языка.

Ключевые слова: Канада, иммерсионное образование, иммерсионные программы, мультилингвизм.

Ustimenko V. V. Immersion education in Canada as an effective method of learning second language.

The article examines the experience of using French immersion programs in education of Canada, characteristics of such type of training are shown taking into consideration the requirements of modern Canadian society. The special attention is paid to the effectiveness of immersion education while learning second language.

Key words: Canada, immersion education, immersion programs, multilingualism.

В останні десятиліття проблема підготовки людей до життя в багатонаціональному суспільстві в умовах багатомовності та полікультурності перебуває в центрі уваги педагогічних досліджень. Як відомо, мета і зміст будь-якої 